Jan N. M. Schieveld

\title{
On grief and despair versus resilience and personal growth in critical illness
}

Received: 19 February 2009

Accepted: 23 February 2009

Published online: 10 March 2009

(C) The Author(s) 2009. This article is published with open access at Springerlink.com

This editorial refers to the article available at: doi:10.1007/s00134-009-1444-1.

J. N. M. Schieveld (৫)

Department of Psychiatry and Neuropsychology,

Maastricht University Medical Center+,

P. Debyelaan 25, PO Box 5800,

6202 AZ Maastricht, The Netherlands

e-mail: jan.schieveld@mumc.nl

Tel.: +31-43-3877499

Fax: +31-43-3875444

'Happy families are all alike; every unhappy family is unhappy in its own way' (Leonid Tolstoy, in Anna Karenina, chapter 1, opening line [1])

Human reactions to major life events-whether they are beautiful and good, or horrifying and threatening - are pluriform. How should one cope with these events and with one's own psychological and bodily reactions to them? How can one give meaning to all this and make sense of life again?

The DSM-IV (Diagnostic and Statistical Manual of Mental Disorders, fourth edition [2]) recognizes six major reaction types that occur especially after a major traumatic event, including the critical illness of a beloved family member: adjustment disorder, acute stress disorder, PTSD (post-traumatic stress disorder), bereavement, mood disorder and brief psychotic disorder. In addition, some people start smoking (or take it up again) or drinking (ditto), while others start using benzodiazepines or lose themselves in their jobs. These kinds of major stressors can bring out the best or the worst in the individuals affected. They are a burden on their relationships as well as a test of the strength and endurance of these. They frequently lead to secondary trauma as individuals may seek support and comfort from persons other than the overburdened partner, which in turn may occasionally result in emotional attachments that impact negatively on the relationship.

Across the world and through the ages, man has tried to give meaning to these events. Indeed, anthropos (classical Greek for 'human being') signifies in particular 'the one who looks above in search of meaning'. All major religions and philosophies as well as all of our great composers, writers and film directors have taken their own specific stand in the matter of grief and despair-and often to the great comfort and help of many. Sometimes the significance of it all comes in a flash: 'All great deeds and all great thoughts have a ridiculous beginning. Great works are often born on a street corner or in a restaurant's revolving door' (Albert Camus, 1913-1960). And, to quote from this month's paper by Gillian Colville and Penelope Cream [3], we can add: '...or in the corridor of a PICU (paediatric intensive care unit)'. In their paper 'Post-traumatic growth in parents after a child's admission to intensive care: Maybe Nietzsche was right?', Colville and Cream continue the tradition of the study of traumatic stress and adversarial growth that has thrived since the 1980s [4]. These researchers sent a questionnaire to the parents of 61 children who have been discharged 4 months earlier from the PICU; based on the 43 responses $(70 \%)$, they found that most of these parents (88\%) were able to grow-in a personal context-despite the traumatic event of having a critically ill child in the PICU. Growth was a function of the impact and severity of the stressor and showed, not unexpectedly, an inverted U shape: too little stress, and there is no sense of urgency to find meaning and thus no personal growth; too much 
stress, and the parents are overwhelmed by its acuteness and by their fight-or-flight reactions as well as by such questions as 'How can we survive this disaster?', leaving little-if any-space for personal growth at that time.

Thus, with 'balanced' stress and a 'balanced' impact, many people can find another, more significant meaning to their disaster and acquire the resilience required to pick up and continue their lives. Here, two important lessons are learned: (1) the level of 'sufficient' stress probably varies according to gender and from person to person and from culture to culture; (2) we, members of the multidisciplinary team at the PICU-doctors, nurses and mental health specialists alike-have the responsibility to recognize these facts and understand the mechanisms that underlie the processing of acute stress in our 'extended patients' (the families). This will give them a chance to find a new level of understanding as well as to establish a new balance in their lives. Returning to the question 'Maybe Nietzsche was right?', I can answer 'Yes-but certainly not always and not completely'. In a salute to the authors, with the words of Marcel Proust (18711922): 'Happiness is beneficial for the body, but it is grief that strengthens the soul' [5].

Open Access This article is distributed under the terms of the Creative Commons Attribution Noncommercial License which permits any noncommercial use, distribution, and reproduction in any medium, provided the original author(s) and source are credited.

\section{References}

1. Tolstoy L (1873-1877) Anna Karenina. First published in 'The Russian Messenger', Moscow

2. American Psychiatric Association (2000) Diagnostic and statistical manual of mental disorders, 4th edn. American Psychiatric Association, Arlington, VA
3. Colville G, Cream P (2009) Posttraumatic stress in parents after a child's admission to intensive care: maybe Nietzsche was right? Intensive Care Med. Doi: 10.1007/s00134-009-1444-1
4. Alex Linley P, Joseph S (2004) Positive change following trauma and adversity: a review. J Traumatic Stress 17:11-21

5. Proust M (1913-1927) In search of lost time. Gaston Gallimard, Paris 